\title{
Capture and commercialization of blue land crabs ("guaiamum") Cardisoma guanhumi (Lattreille, 1825) along the coast of Bahia State, Brazil: an ethnoecological approach
}

\author{
Angélica MS Firmo ${ }^{1 *}$, Mônica MP Tognella ${ }^{1}$, Saulo R Silva ${ }^{1,2}$, Raynner RRD Barboza ${ }^{2}$ and Rômulo RN Alves ${ }^{2}$
}

\begin{abstract}
Background: Blue Land Crab (Cardisoma guanhumi) is one of the most important crustacean species captured and commercialized in Brazil. Although this species is not considered to be threatened with extinction, populations of C. guanhumi are known to be rapidly diminishing due to heavy harvesting pressures and degradation of their natural habitats, highlighting the necessity of developing and implanting management and protection strategies for their populations. There have been no ethnozoological publications that have focused specifically on C. guanhumi, in spite of importance of this type of information for developing efficient management plans of resource utilization. So, the present work describes the ethnoecological aspects of the capture and commercialization of C. guanhumi by a fishing community in northeastern Brazil.

Methods: Field work was carried out in the municipality of Mucuri, Bahia in Brazil, between the months of January and March/2011 through the use of open semi-structured interviews with all of the crustacean harvesters in city who acknowledged their work in capturing this species, totaling 12 interviewees. The informants were identified through the use of the "snowball" sampling technique. In addition to the interviews themselves, the "guided tour" technique and direct observations was employed.

Results: According all the interviewees, the C. guanhumi is popularly called "guaiamum" and is collected in "apicum" zones. They recognize sexual dimorphism in the species based on three morphological characteristics and the harvesters also pointed two stages in the reproductive cycle during the year and another phase mentioned by the interviewees was ecdysis. All of the interviewed affirmed that the size and the quantities C. guanhumi stocks in Mucuri have been diminishing. All of the interviewees agreed that the species and other mangrove resources constituted their principal source of income. The harvesters dedicated three to five days a week to collect Blue Land Crabs and the principal technique utilized for capturing is a trap called a "ratoeira" (rat-trap).
\end{abstract}

Conclusions: The results of the present work demonstrated that the community retains a vast and important volume of knowledge about C. guanhumi that could subsidize both scientific studies and the elaboration of viable management and conservation strategies for this species.

Keywords: Crab harvesters, Environmental perception, Mangrove, Conservation

\footnotetext{
* Correspondence: angelicascaldaferri@yahoo.com.br

'Departamento de Ciências Agrárias e Biológicas, Programa de Pós

Graduação em Biodiversidade Tropical (Ecologia), Universidade Federal do Espírito Santo/Centro Universitário Norte do Espírito Santo - UFES/CEUNES,

São Mateus, Brazil

Full list of author information is available at the end of the article
} 


\section{Background}

Mangrove ecosystems are restricted to intertidal coastal zones in tropical and subtropical regions. These transitional environments are characterized by high levels of primary productivity and high capacities for transforming nutrients into organic material [1]. Mangrove swamps are encountered along almost the entire Brazilian coast from the Oiapoque River in the state of Amapá in the north to Laguna, in the state of Santa Catarina [2] and they occupy a total area of approximately $25,000 \mathrm{Km}^{2}$ [3]. The ecological services furnished by mangrove swamps are quite numerous and include protecting against coastal erosion, preventing inland flooding, and maintaining coastal biodiversity [4].

In addition to their ecological importance, mangrove swamps furnish a wide spectrum of natural products to human populations, such as: wood, fish [5], crustaceans, mollusks, dyes [6], charcoal, tannins, and plant medicines [7], and coastal communities throughout the world depend on these areas for their subsistence $[3,8,9]$. Brachyura crustaceans are one of the most economically important resources of estuarine communities in Brazil $[1,10,11]$.

Among the most important crustacean species captured and commercialized in Brazil are: the Blue Land Crab ("goiamum") (Cardisoma guanhumi), the Mangrove Root Crab ("aratu") (Goniopsis cruentata), the Swimming Crab group ("siris") (Callinectes spp.), and the Mangrove Crab ("caranguejo-uçá") (Ucides cordatus) [12,13]. The Blue Land Crab is a semi-terrestrial species that lives in mangroves above the high tide line $[14,15]$ in Brazil between the states of Ceará and Santa Catarina $[14,16]$ and is of significant economic importance in the northeastern region of that country. Although this species is not considered to be threatened with extinction, populations of C. guanhumi are known to be rapidly diminishing due to heavy harvesting pressures and degradation of their natural habitats $[17,18]$ - which has motivated their inclusion on the National List of invertebrate aquatic and fish species that are threatened, over-exploited, or threatened with over-exploitation (Normative Instruction $n^{\circ} 5$, of 21 of May of 2004) [19].

The harvesting pressure felt by this crustacean as well as the ongoing degradation of their habitat both highlight the necessity of developing and implanting management and protection strategies for their populations. These efforts will in turn require additional research on the biological aspects of this species as well as ethnoecological investigations directed towards the socioeconomic aspects of harvesting activities. The few published works available about this species deal mostly with its occurrence and distribution [16,20-23]. A recent ethnozoological review by Alves and Souto [24] listed a total of 23 publications focusing on ethnocarcinology in Brazil, most of them dealing with the species Ucides cordatus (Swamp Ghost Crab) [6,25-31]. There have been no ethnozoological publications that have focused specifically on Cardisoma guanhumi, in spite of importance of this type of information for developing efficient management plans of resource utilization [32-36]. Information about the biology of this species associated with the accumulated empirical knowledge of the human populations that use these resources can furnish important subsidies to improve regulations designed to rationalize the harvesting and management of natural stocks of this species.

The present work describes the ethnoecological aspects of the capture and commercialization of C. guanhumi by a fishing community in northeastern Brazil. It is designed to provide a better understanding of the environmental perception of the fishermen there within their own socioeconomic context and to provide subsidies for the establishment of social programs that can better the lives of these workers and simultaneously aid in conserving this valuable natural resource.

\section{Methods}

\section{Study area}

Field work was carried out in the municipality of Mucuri, in the extreme southern part of the state of Bahia $\left(18^{\circ}\right.$ $05^{\prime} 46^{\prime} \mathrm{S}, 39^{\circ} 33^{\prime} 13$ “W) (Figure 1). The region is composed of coastal plains covered by generally low vegetation, with dense "restingas" (sandy coastal areas) and small remnant patches of Atlantic Forest, as well as an exuberant mangrove swamp [37]. Many of the residents of Mucuri make their living from fishing and harvesting crustaceans in this mangrove area [38].

\section{Data collection and analyses}

Information related to ethno-carcinological knowledge about C. guanhumi was obtained through the use of open semi-structured interviews with all of the crustacean harvesters in Mucuri who acknowledged their work in capturing this species, totaling 12 interviewees. We elaborated 29 questions dealing with their ecological and biological knowledge of these animals as well as the techniques used in harvesting, storing, and commercializing the crabs. The informants were identified through the use of the "snowball" sampling technique, in which interviewees are chosen based on the recommendations of other informants [39].

Of the twelve crab-harvesters interviewed, all were men between 18 and 51 years old (average 30). Their work experience as harvesters varied from 5 to 35 years (average 22 years).

In addition to the interviews themselves, the "guided tour" technique [40] was employed in excursions into 


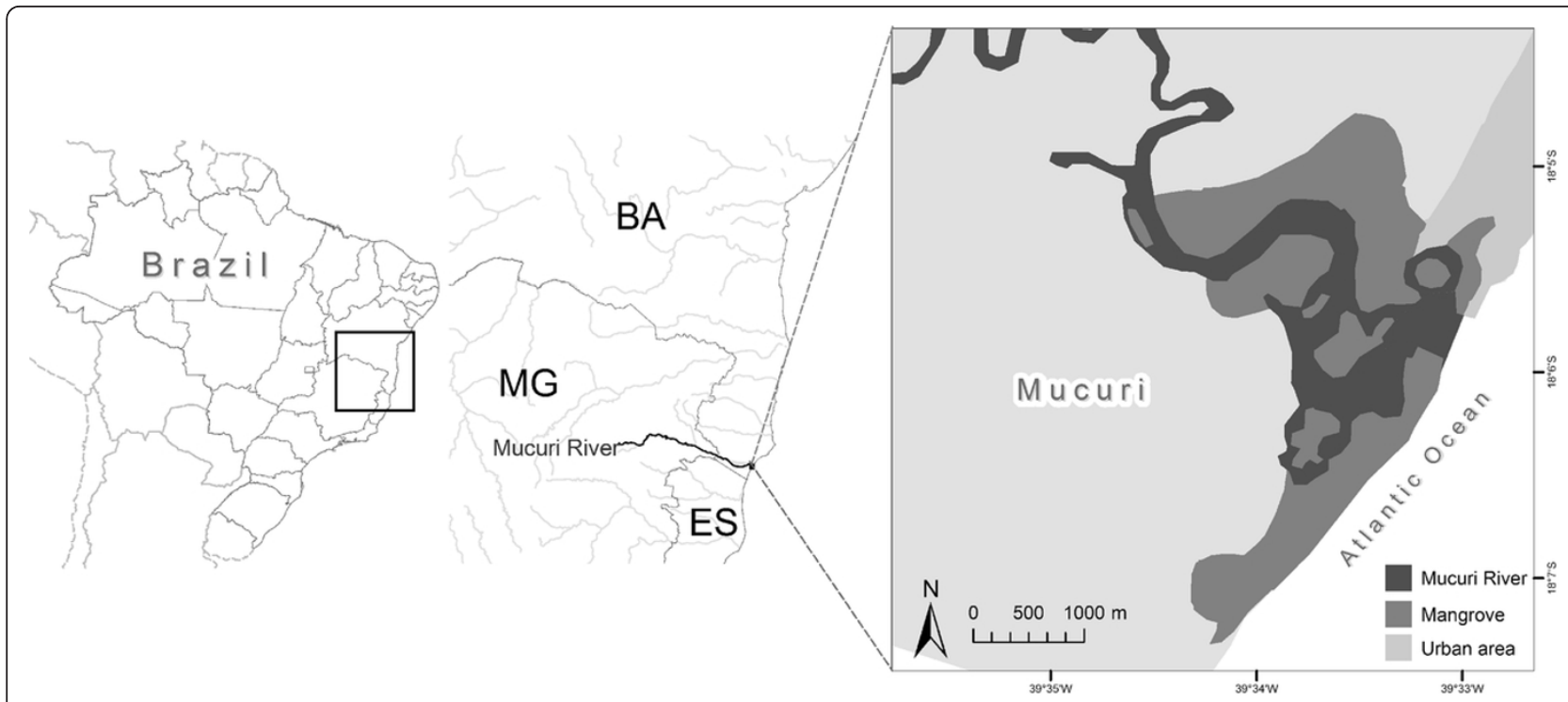

Figure 1 Map of the Mucuri River estuary, Bahia state, Brazil.

the interior of the Mucuri mangrove accompanied by fishermen to make first hand observations of the activities involved in capturing the crabs. As many questions could not be answered solely through the use of questionnaires, this information was complemented through direct observations (equivalent to the non-member participant observer technique) [41] that allowed close contact between the researcher and the group being studied and facilitated a better comprehension of the information presented [42].

The data was analyzed qualitatively, considering all of the information presented by the interviewees [43]. Two control techniques were adopted to confirm the validity of the information: synchronic situations, in which the same question was presented to different people at approximately the same time; and diachronic situations, in which the same question was submitted to the same individual at distinct time intervals [44].

The present study was approved by the ethics and research committees of the Federal University of Espírito Santo/University Center North of Espírito Santo (UFES/CEUNES). All of the interviews were undertaken between the months of January and March/2011 during previously arranged visits to the residences of the fishermen, or in previously determined alternative localities. Photographic records were made whenever possible, and field data was recorded digitally and subsequently transcribed in the form of texts or tables. The interviews were always preceded by the interviewer's identification with a brief explanation about the purpose of work and a written consent and permission for publication of the images were given by those interviewed.

\section{Results and discussion}

Ethno-carcinological knowledge

The Blue Land Crab, Cardisoma guanhumi, is popularly called "guaiamum" by fishermen and residents of Mucuri, although other regional variations of the term are used in other coastal localities, such as "guaiamu" or "goiamum" [36].

According all the interviewees in the research area, this crustacean is collected in "apicum" zones (Figure 2), which Soares [45] described as corresponding to generally flat areas with high salinity and acidic levels located above the high-tide line and lacking vegetation (or with only sparse, low growth). The information provided by the local fishermen agreed with published accounts that indicate that Blue Land Crabs normally occupy higher regions of the mangrove swamp above the high-tide line, where the terrain is usually more sandy [46].

The interviewees indicated the existence of two basic types of mangrove areas: "enxuto" (dry) sites where Blue Land Crabs are found, and the "mole" (soft) sites that are preferred by the Mangrove Crab, Ucides cordatus. The latter species is known to inhabit galleries carved into soft substrates in the intermediate zone between the high and low tides [30], while the Blue Land Crabs carve their tunnels into higher, sandy ground, while maintaining a small amount of water in bottom of its den. According to the interviewees, Blue Land Crabs normally construct their galleries in the "apicum" zone where the vegetation is distinct from that encountered in the mangrove swamp itself [47].

The harvesters recognized sexual dimorphism in the species based on three morphological characteristics. 


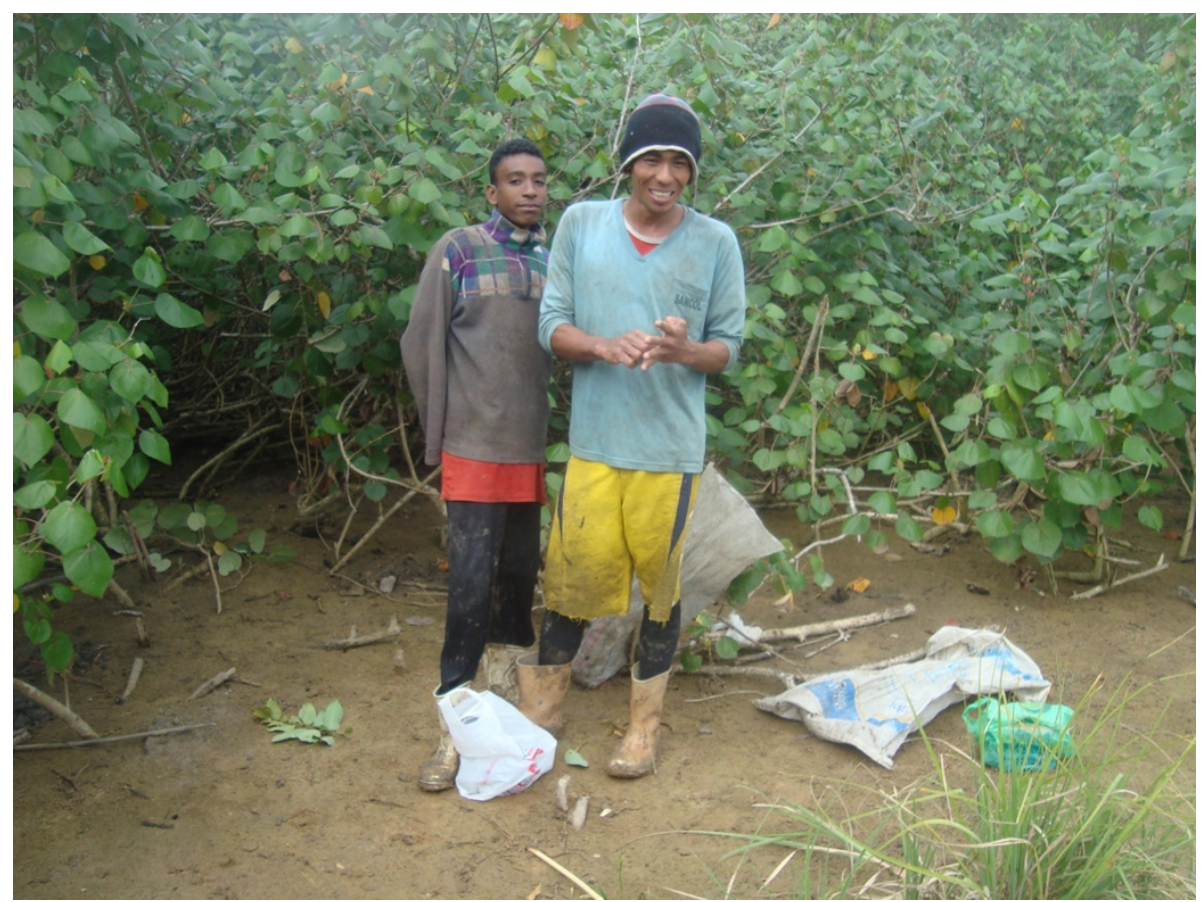

Figure 2 Crab Collectors in an "apicum" zone of the Mucuri mangrove.

The first is related to differences in the shapes and sizes of the abdomen (which they call the "imbigo"). The males have thinner and smaller abdomens, while those of the females are larger and wider (and are designated "Apupê") (Figure 3) and are used to carry their eggmasses $[48,49]$. The same sexual differentiation based on abdomen size was described in studies undertaken in other northeastern mangrove swamps involving the species $C$. guanhumi and $U$. cordatus [50-52]. This type of sexual differentiation was also observed among Swimming Crabs (Callinectes spp.) [53], Mangrove Root Crabs (Goniopsis cruentata) [54], and Mangrove Crabs $[12,38,55,56]$. The second morphological difference between the sexes cited by the interviewees was related to their coloration, which could be bluish or purple in males and white in females. According to Gifford [57], young individuals of C. guanhumi are purple; the males become bluish or grey-blue when older, while the females become yellow-orange or whitish. These observations were corroborated by the crustacean harvesters. It must be noted, however, that both sexes can become notably bluish (or exhibit brownish or whitish variations) during ecdysis (molting) [55]. Size was the third factor of sexual differentiation pointed out by the fishermen, with the males being generally larger than the females. This difference, in addition to being common among crustaceans, can also occur in response to factors such as reproductive migration, behavioral variations, and differences in life phases or mortality rates $[58,59]$.
The crab-harvesters interviewed in Mucuri reported that they could distinguish between the tunnels of the Blue Land Crab males and females by observing the feces left at their entrances. A similar observation was reported by Takahashi [60] among Blue Land Crab harvesters living in four municipalities in the state of the Paraíba, Brazil. The interviewees in Mucuri indicated that the feces of the males are longer and thinner (Figure 4) than those of the females (Figure 5). The architecture of the tunnels can also indicate the sex of the animals, as the males construct long, inclined burrows, while the females construct straighter and more rounded burrows. The sexual differentiation of some species of crustaceans using morphological and behavioral characteristics has been reported by other crustacean harvesters [12,52,61-64].

The interviewees also noted that there was a relationship between the sizes of the animal and the sizes of their burrows. The Blue Land Crabs that these fishermen capture are initially selected using the criteria of tunnels size - for if the worker can fit his hand inside the burrow the animal is presumably large enough to be worth taking. The interviewees also noted that the females prefer softer soils and the males harder substrates. The harvesters also pointed out that individuals of $C$. guanhumi live solitary lives and spend most of their time within their galleries, leaving them only to feed, mate, or lay their eggs. According to Gifford [57], the upper section of the gallery is usually vertical, or very nearly so. Generally, only a single individual occupies a burrow; the males tend to be more territorial 


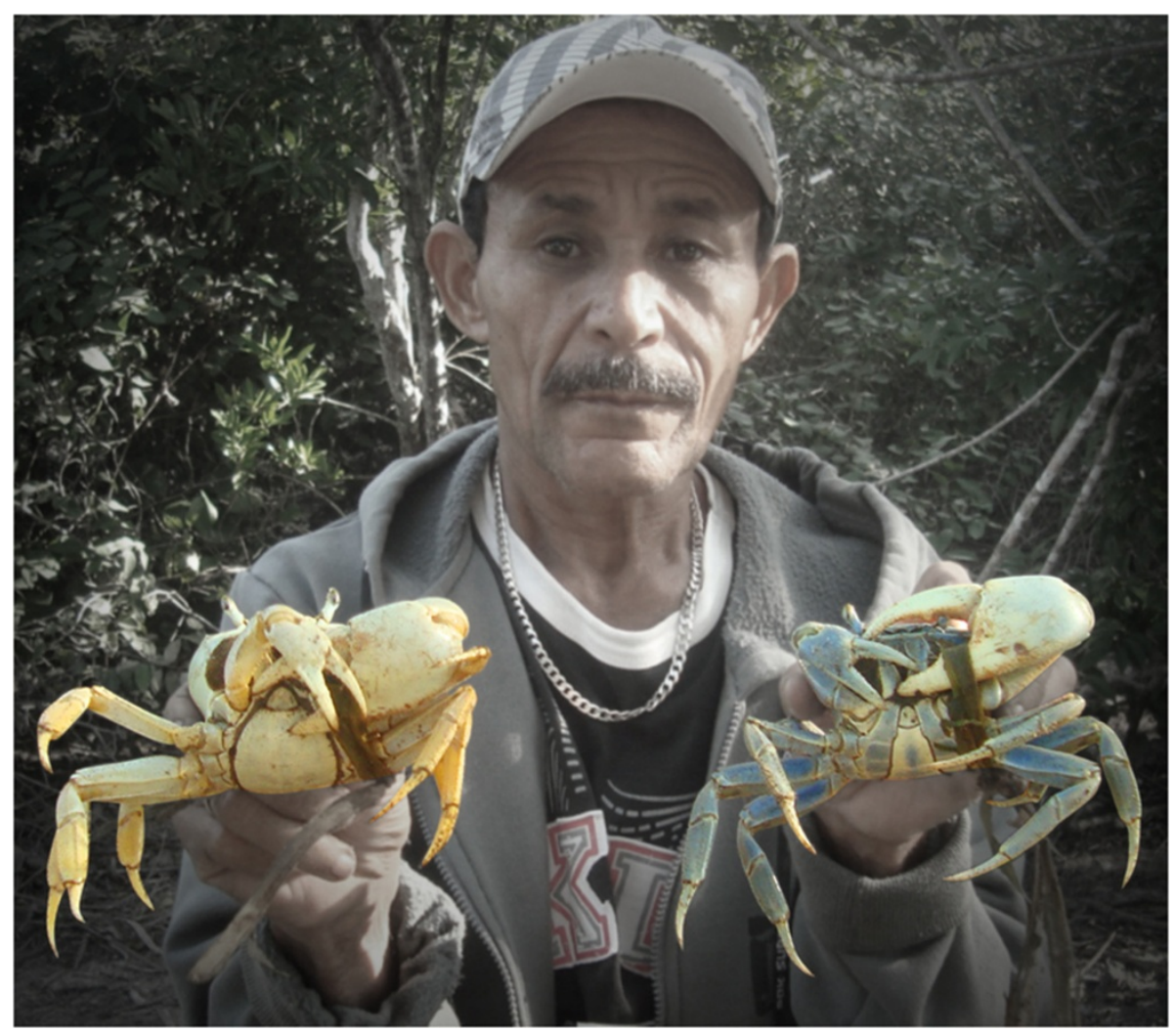

Figure 3 Collector showing sexual dimorphism of the species C. guanhumi.

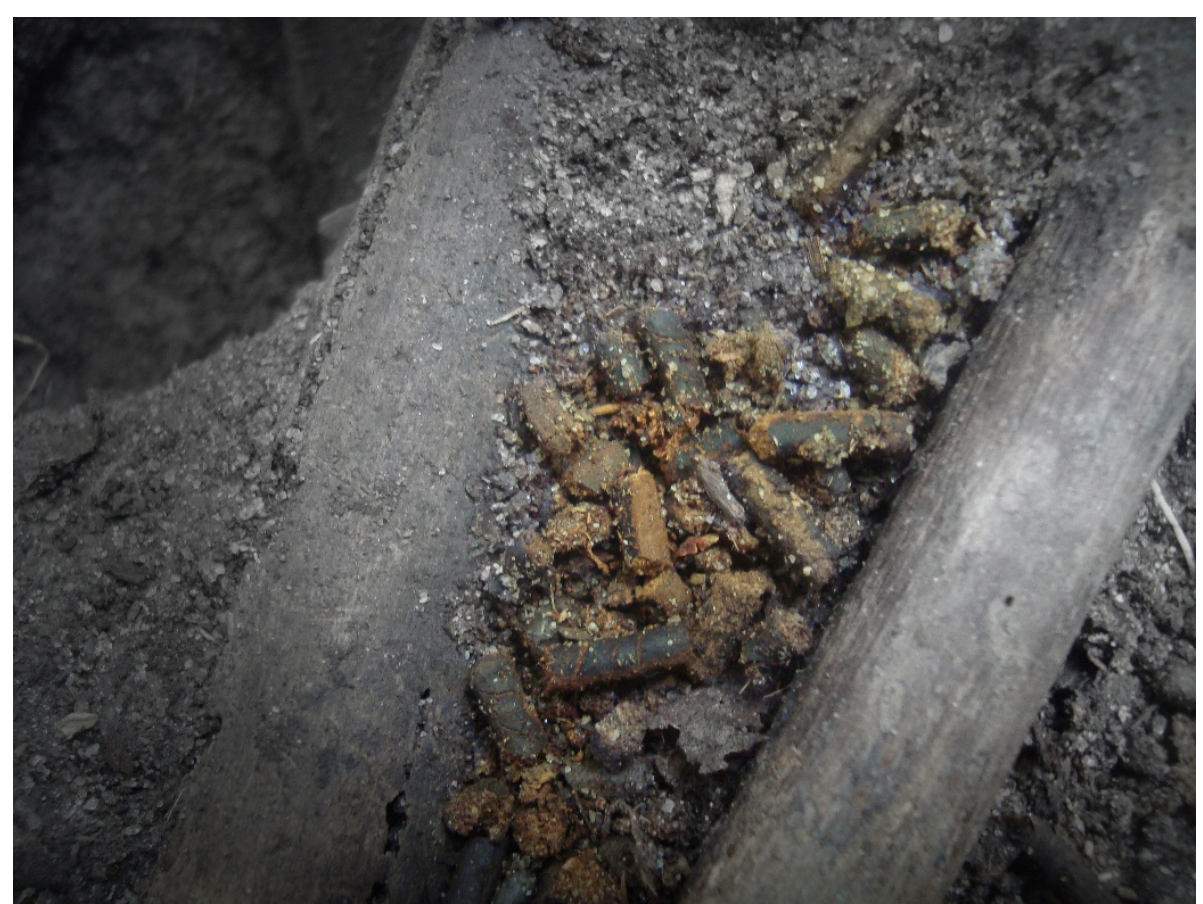

Figure 4 Feces of a male specimen of $C$. guanhumi, according to the collectors. 


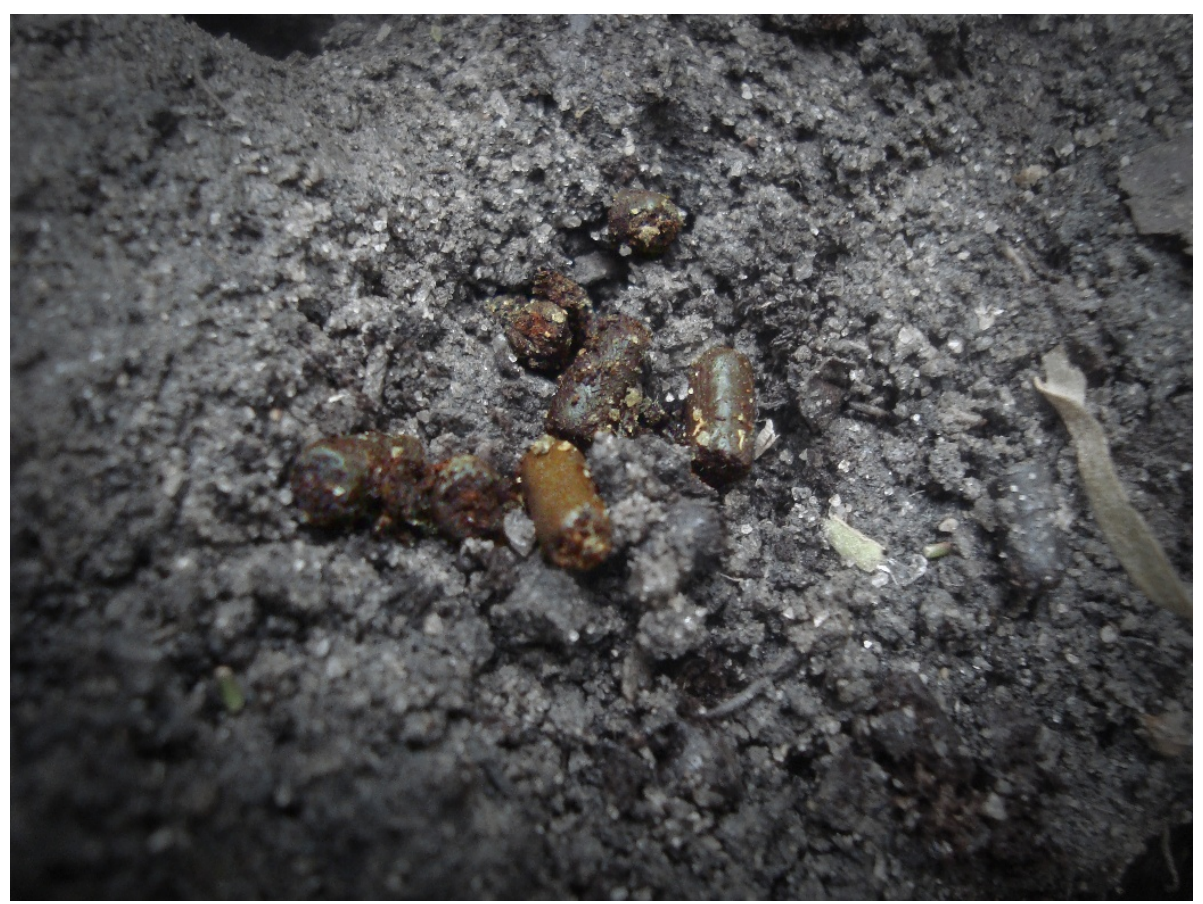

Figure 5 Feces of a female specimen of $C$. guanhumi, according to the collectors.

than females and will defend their burrows and small surrounding territories [48].

In terms of the trophic ecology of Blue Land Crabs, all of the interviewees agreed that this species consumed just about any resource available, including dead animals. This information corroborates Bright and Hogue [65] who noted that Blue Land Crabs are primarily herbivores that consumes vegetal material available in the sediment (e.g. the leaves of mangrove trees, flowers, etc.), although it can eat many other available items, such as small animals and decomposing plants. According to Hill [48], the basic food of this species is composed of red-mangrove (Rhizophora mangle) and white-mangrove (Laguncularia racemosa) leaves, as well as fruits and grasses.

The crab harvesters interviewed noted that there were two stages in the reproductive cycle of C. guanhumi during the year - the "andada" (walking about) (which is the mating period of these animals and occurs between January and March); and the "andada das fêmeas" (females walking about), or egg-laying phase between April and May. This information is consistent with the study undertaken by Botelho et al. [16] along the coast of the state of Pernambuco in which it was reported that the most intense reproductive period of these crabs occurred between December and February, and with Silva and Oshiro [66] who studied the reproduction of Blue Land Crabs in Sepetiba Bay in the state of Rio de Janeiro. According to a study undertaken by Gaião [67], the reproductive cycle of the Blue Land Crab initiates with the "andada" phase when the crabs leave their burrows in search of breeding partners. With the end of the "andada", the females begin their "desova" (egg-laying). It is worth noting that all of the interviewees stated they could distinguish between the mating and the egg-laying "andadas". This species reaches sexual maturity after approximately three or four years [48]. The crab harvesters recognize the sexual maturity of the Blue Land Crabs as being related to their size, when the animal has a carapace that is about $6 \mathrm{~cm}$ wide. This width is very close to that reported in the literature [51] as corresponding to sexual maturity (carapace $5.85 \mathrm{~cm}$ wide).

Another phase mentioned by the interviewees was ecdysis (called "descasca" by the crab harvesters). Although this phase does not occur simultaneously throughout the population, the interviewees reported that it was most common between July and August, when the animals are generally well-fed. According to Alves and Nishida [30] and Nunes [68], crustaceans such as $U$. cordatus stock their burrows with leaves and seal the tunnel mouth with mud in the period preceding ecdysis. The Mucuri crab harvesters stated that ecdysis in C. guanhumi can last one or two weeks, terminating between the months of September and October, when all of the animals will have completely molted. These animals then appear thinner due to the long periods spent inside their burrows during the molt. Nascimento [69] noted that this process allows the animals to increase in size, and is more frequent with animals in their larval 
and immature phases. Hill [48] observed that C. guanhumi will undergo up to 60 molts before reaching its adult phase, although these periods of ecdysis become less frequent with age. Blue Land Crabs (as well as the Mangrove Crab) are inappropriate for human consumption during this period and can cause serious collateral effects [55] and are popularly called "caranguejos de leite" (milk-crabs) due the secretion of a whitish liquid responsible for hardening the carapace [70]. This phenomenon occurs only in some species of crabs semiterrestrial and terrestrial [71].

The biological cycles of many species that live in estuaries and mangrove swamps are heavily influenced by lunar cycles [30,72,73], and this might also be expected to affect human fishing activities [12,30,73,74]. All of the interviewees stated, however, that the lunar cycles and different tides did not interfere in the availability or harvesting of C. guanhumi. The only abiotic interference they mentioned was related to environmental temperatures, as these crabs do not react well to heat, preferring cooler temperatures and a rainy climate. The fishermen noted that when temperatures approached $40^{\circ} \mathrm{C}$ in the summer these crustaceans will rarely leave their burrows, making it more difficult to capture them. The optimal temperature for larvae development in this species in the laboratory was found to be between 25 and $30^{\circ} \mathrm{C}$ [48].

The crab gatherers reported that in addition to humans, Blue Land Crabs suffer natural predation from a mammal they call "Mão Lisa" (Procyon cancrivorus) (the Crab-Eating Raccoon), which eats both C. guanhumi and $U$. cordatus. According to these same fishermen, however, the relationship between them and the raccoon is quite neutral as they do not interfere with harvest production. This same species was also identified by the Blue Land Crab gatherers in the state of Paraíba as the most significant predator of C. guanhumi [60].

All of the crab harvesters interviewed affirmed that the sizes and the quantities of C. guanhumi stocks in Mucuri have been diminishing, principally due to pollution, destruction of the harvesting areas by fire, the conversion of mangrove areas to pasture for cattle, and over-exploitation by humans. Diminishing populations of C. guanhumi and other crustaceans in mangrove areas have likewise been reported by various other works $[6,31,74,75]$. Leite [51] stated that a large part of the population decline seen in C. guanhumi is a result of habitat losses.

According to the interviewees, there was a mass die-off of $U$. cordatus in 2005 that eliminated approximately $90 \%$ of the population of that crustacean in the area around Mucuri. This die-off apparently did not affect C. guanhumi, although it did provoke increased harvesting pressure on its populations. A similar situation was reported by Alves and Nishida [6,30] in the Mamanguape
River estuary, PB, where a population crash of Ucides cordatus resulted in increased pressure on other crustacean species that had formerly been little used (putting their stocks at risk as well). The disease that caused the mortality of Ucides cordatus was called Lethargic Crab Disease [76] and was caused by the Ascomycota fungus, identified as "Exophiala cancerae" [77]; it apparently attacked $U$. cordatus almost exclusively.

\section{Local production practices}

All of the interviewees agreed that the harvesting of Blue Land Crabs and other mangrove resources constituted their principal source of income. Seven of these men stated that they complemented their crab harvesting incomes by collecting other animals, such as the Mangrove Crab (4 interviewees) and by fishing $(n=2)$. One of the interviewees complemented his income by working in construction. This same sort of economic diversity was also reported in a study by Leite [51], with a number of Blue Land Crab collectors reporting that they also took on other jobs to add to the family income.

Most of the Blue Land Crab collection points are accessible by canoes ("bateras") that are propelled by rowing or by small gasoline motors. These boats are locally made, usually by the crab-harvesters themselves, and very few of the collection points can be reached on foot. The harvesters set aside three to five days a week to collect Blue Land Crabs, with daily efforts of from three to eight hours. As the collection areas ("apicuns") are located in the upper portions of the mangrove swamp [78], the harvesters do not have fixed working hours, although they are also not structured around tidal schedules - a situation quite distinct from that of other workers dependent on mangrove resources [73].

The principal technique utilized for capturing Blue Land Crabs is a trap called a "ratoeira" (rat-trap) [15,79-81]. According to the interviewees, up until 2002 this device had been made exclusively from wood (Figure 6), but another crab-harvester from the state of Pernambuco introduced a new technique of making these traps using a plastic soda bottle fitted into a 6-inch PVC pipe and a wooden lid that was attached by rubber straps and triggered by a bait stick (Figure 7). When an animal (crab) triggers the trap by pulling on the bait, the door slams shut over the mouth of the tube. Other authors have described the use of this trap to capture the same species [12,51,82-84].

All of the interviewees have since substituted their wooden traps with plastic tube traps, in large part due to the facility in transporting them. The interviewees further explained that these traps do not injure the crabs before their sexes and sizes can be determined, and their use should not be considered a predatory practice. The use of these traps was, however, declared a predatory technique 


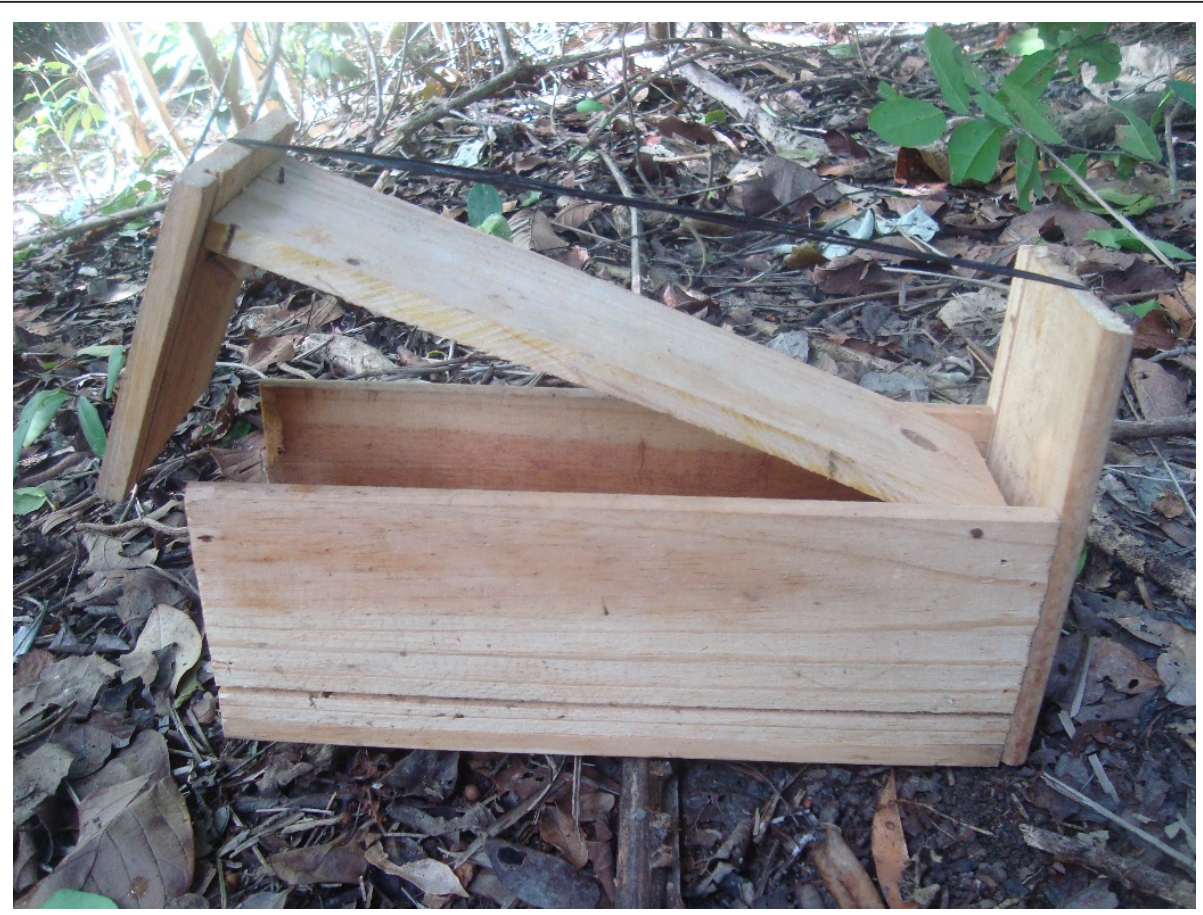

Figure 6 Rat trap ("ratoeira") used to capture C. guanhumi until 2002, made of wood

by federal authorities in 1994, although they were legalized again in 2006.

The harvesters carry between 15 and 50 traps on each outing that they set up near the openings of the crab dens and camouflage with leaves and mud (also fixing them to the sandy ground with sticks). The daily production of crabs is up to about 30 specimens per collector. The traps are generally set and then checked after

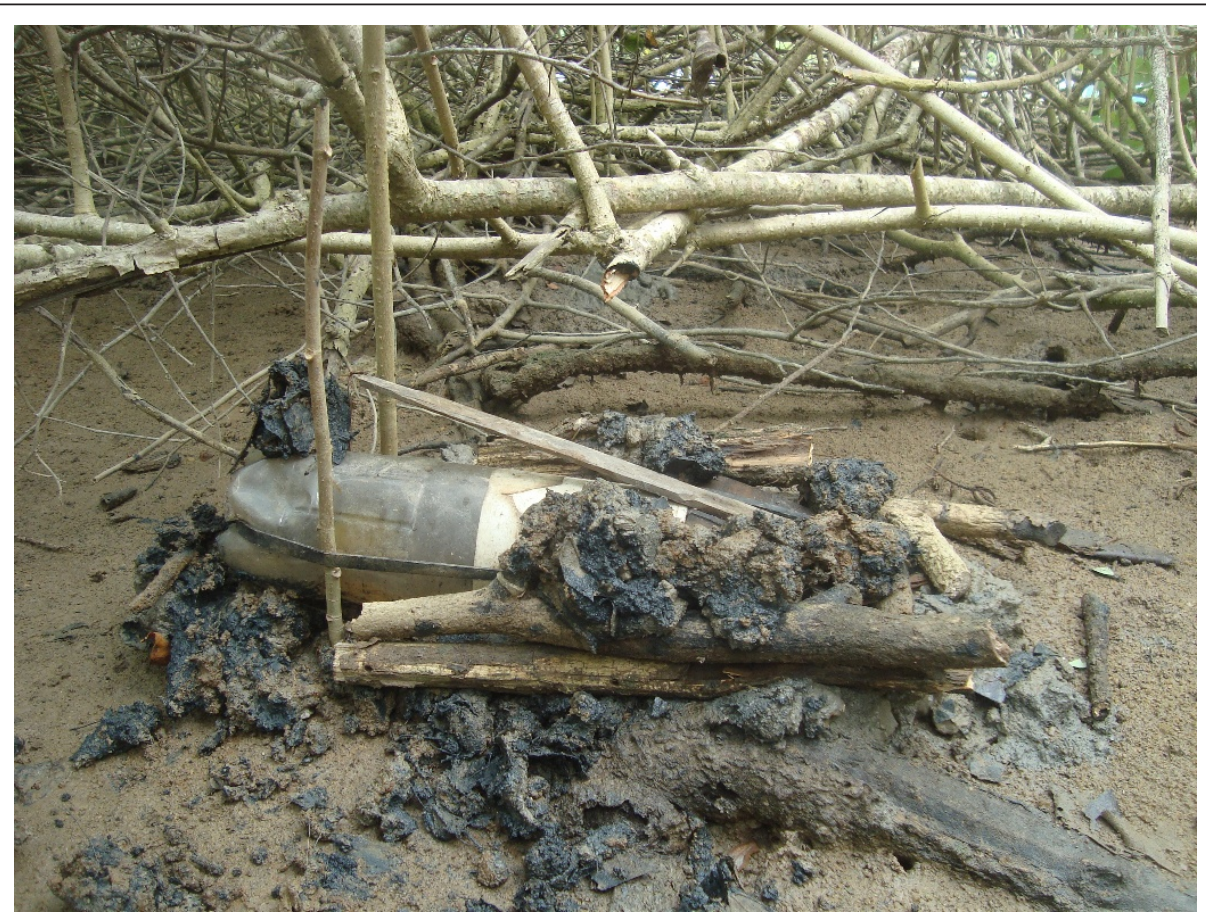

Figure 7 Rat trap currently used by the collectors and made from plastic bottles and PVC pipe. 
one hour. Only two of the interviewees set their traps and then returned on the following day to collect them.

The bait used in the traps will depend on resources available at the moment. The baits most frequently used include: lemons (Citrus spp.), onions (Allium cepa), corn (Zea mays), dendê-palm fruits (Elaeis guineensis), jack fruit (Artocarpus heterophyllus), sugar cane (Saccharum spp.), genipap fruits (Genipa americana), pineapples (Ananas comosus), and "gravatá" (Bromelia pinguin). The latter three are most favored as, according to the harvesters, sweeter and more aromatic baits are most successful. These types of bait have been reported in earlier publications $[15,80,85]$. The captured animals are subsequently bound with "imbira" (Figure 8) twine (which is made from strips of bark from the trunk of the Seaside Mahoe (Hibiscus pernambucensis) and then placed in large gunny sacks for transport.

At the end of the day the crabs are taken to the harvester's house and freed into storage pits called "chiqueiros" or "tanque de engorda", where they are kept and raised for up to 30 days (although they can be sold at any time, according to the necessities of the fishermen and/or demand). According to Gaião [67], Blue Land Crabs feed on essentially anything they find (such as the remains of dead animals and feces) and can thus accumulate toxins. The harvesters are aware of the details of their diets and for the first week after their capture they are fed only lemons to "clean" out their systems. During subsequent weeks they will be offered various other types of foods to gain weight. Gaião [67], Duarte [86], and Lima [87] likewise documented the fattening of these crabs while in captivity. The holding tanks may store up to an acceptable maximum of about 100 live animals. Generally, the smaller Blue Land Crabs are separated from the larger specimens and held in smaller tanks to avoid cannibalism. Cannibalism has frequently been observed under captive conditions [60] and it is believed that this species may exhibit this same behavior in their natural environment [48].

Most Blue Land Crabs are commercialized locally, being sold by the fishermen from their own houses to buyers that live in Mucuri. Very few crabs are sold to the owners of small seaside restaurants, as the city has apparently been loosing its former intense tourist appeal. The crabs are sold for between US\$1.60 and $\$ 3.20$ each, depending on their size. This value does not vary much, so that the fishermen tend to earn between US\$230 and $\$ 650$ per month throughout the year. Only three interviewees indicated that they sold their catches to buyers from neighboring cities.

According to Normative Instruction $\mathrm{N}^{\circ} 90 \mathrm{DOU}$ 06.02.2006, the Brazilian Institute of the Environment and Renewable Natural Resources (IBAMA) [88] is the responsible for regulating the capture, storage, transport, industrialization, and commercialization of C. guanhumi in northeastern Brazil.

When questioned about capturing C. guanhumi during the period when harvesting is officially prohibited

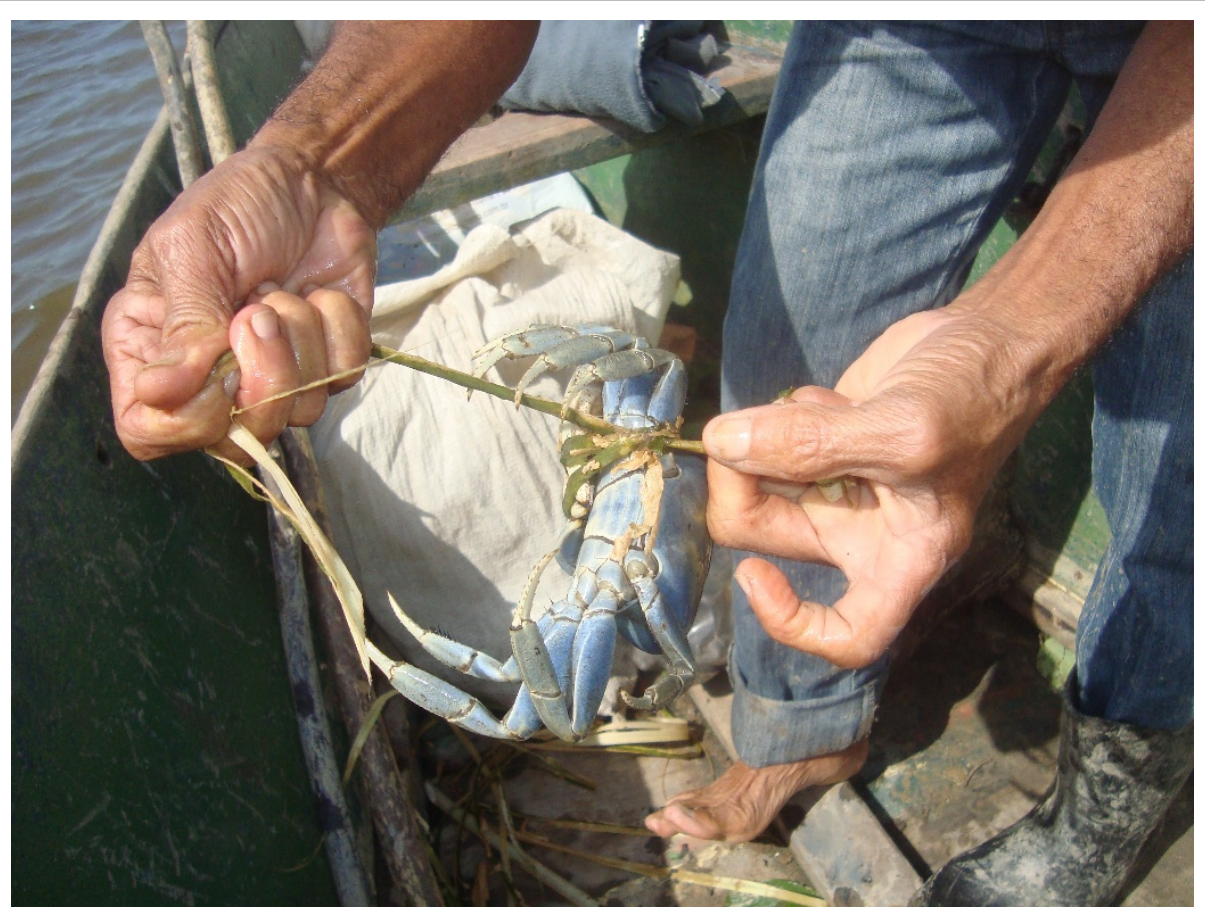

Figure 8 Collector using the "imbira" twine to bind the land crabs that are picked. 
(December to March) (according to Article $2^{\circ}$ of regulation N.I. 90/2006), all of the interviewees indicated that they were aware of this non-harvesting period although only eight of them knew the correct dates. Those did that did not know the correct dates of the prohibition period indicated that they did not follow this rule anyway because it was inadequate for the region and did not coincide with the egg-laying period of C. guanhumi in Mucuri. This situation demonstrates the necessity of regional studies that can use the knowledge of local fishermen to correctly determine the defense periods for crab reproduction and more adequately manage and conserve these species.

The interviewees stated that although they respected the legislation prohibiting the capture or sale of female crabs in the state of Bahia at any time of the year (Article $1^{\circ}$ of N.I. 90/2006), it is not commercially feasible to just sell males. Additionally, the carapaces of the Blue Land Crabs sold in Mucuri have a minimum size of $6 \mathrm{~cm}$, which demonstrates the circumvention of yet another federal regulation that prohibits capturing individuals of this species withcarapaces smaller than $7.0 \mathrm{~cm}$ (Article $4^{\circ}$ of N.I. 90/2006). The interviewees noted that their preoccupation with regards to the sex of the crabs and the conservation of the species was not shared by the buyers (who were more interested in the sizes, and therefore the commercial values, of the animals).

\section{Conclusions}

The results of the present work demonstrated that the community of crab harvesters in Mucuri retains a vast and important volume of knowledge about C. guanhumi that could subsidize both scientific studies and the elaboration of viable management and conservation strategies for this species. In light of the significant importance of this species in Brazil, ethnoecological studies should be encouraged as they aggregate additional information to scientific projects that can in turn be used to formulate plans for the sustainable use of this mangrove resource. IBAMA recently elaborated a national plan for managing economically important crustacean species, including Blue Land Crabs [5]. In addition to suggesting norms regulating the types of traps used to capture Blue Land Crabs, the plan points to the necessity of developing educational activities within fishing communities as well as more adequate monitoring and control of the mangrove swamp itself. As such, the plan recommends reductions in collections in this environment, with restrictions of human presence in the higher regions of the mangrove swamp above the high-tide line areas ("apicum") so that the galleries of young crabs will not be damaged or destroyed by foot traffic. It also recommends prohibiting the practice of commercializing isolated parts of these animals (claws). Additionally, the plan cites the necessity of the establishing specific extraction and exclusion areas. It will therefore be necessary to identify (through geo-processing technologies and physiographic characterizations) "apicum" regions (exclusion areas) and "restinga" sites (extraction areas with greater densities of adult individuals). It is hoped that our results will be useful in future revisions of the present plan and that it will incorporate the accumulated traditional knowledge and experience of populations that use these estuary resources.

\section{Acknowledgements}

The authors would like to thank all the crab harvesters interviewed. We also thank Fernando Firmo and Valéria Scaldaferri for their contribution in data collection during the survey

\section{Author details}

'Departamento de Ciências Agrárias e Biológicas, Programa de Pós Graduação em Biodiversidade Tropical (Ecologia), Universidade Federal do Espírito Santo/Centro Universitário Norte do Espírito Santo - UFES/CEUNES, São Mateus, Brazil. ²Departamento de Biologia, Programa de Pós-Graduação em Ciências Biológicas (Zoologia) Universidade Estadual da Paraíba - UEPB, Paraíba, Brazil.

\section{Authors' contributions}

AMSF wrote all the parts of the manuscript, literature survey and interpretation and conducted the data collection. MMPT, RRDB, SRS and RRNA wrote some parts of the manuscript, ethnozoological data, literature survey, interpretation and revision of the manuscript. AMSF and MMPT analysis of taxonomic aspects. AMSF and SRS participated in data collection during the survey. All authors read and approved the final manuscript.

\section{Competing interests}

The authors declare that they have no competing interests.

Received: 12 December 2011 Accepted: 19 March 2012

Published: 19 March 2012

\section{References}

1. Schaeffer-Novelli Y: Manguezal: ecossistema entre a terra e o mar Caribbean Ecological Research. São Paulo: Academic Press; 1995.

2. Schaeffer-Novelli Y: Manguezais brasileiros. Tese Doutorado Universidade de São Paulo, Instituto Oceanográfico de São Paulo; 1991.

3. Saenger $P$, Hegerl EJ, Davie JDS: Global status of mangrove ecosystems. Environmentalist 1983, 3(Suppl3):1-88.

4. Tognella MMP, Lugli DO, Oliveira RG, Schaellenberger BH, Willrich JF: Avaliação do Replantio da Vegetação do Manguezal no Saco da Fazenda, Itajaí (SC). Notas Técnicas Facimar 2004, 8:39-43.

5. Dias TLP: Os Peixes, a Pesca e os Pescadores da Reserva de Desenvolvimento Sustentável Ponta do Tubarão (Macau-Guamaré/RN), Brasil. Tese Doutorado Universidade Federal da Paraíba. Programa de PósGraduação em Ciências Biológicas (Zoologia), Departamento de Sistemática e Ecologia; 2006

6. Alves RRN, Nishida AK: Aspectos socioeconômicos e formas de percepção ambiental dos catadores de caranguejo-uçá Ucides cordatus cordatu (L. 1763) (Decapoda, Brachyura) do estuário do rio Mamanguape. Interciencia 2003, 28:36-43.

7. Marques JGW: Etnoecologia, educação ambiental e superação da pobreza em áreas de manguezais [abstract]. Anais do $1^{\circ}$ Encontro Nacional de Educação Ambiental em Áreas de Manguezais, Maragogipe, Brasil 1993, 5:530

8. Hamilton LS, Snedaker SC: Handbook for Mangrove Area Management UNEP and East West Center, Environment and Policy In stitute; 1984.

9. Walters BB, Rönnbäck P, Kovacs J, Crona B, Hussain S, Badola R, Primavera J, Barbier EB, Dahdouh-Guebas F: Ethnobiology, socioeconomics and adaptive management of mangroves: a review. Aquat Bot 2008 89:220-236. 
10. Jankovski M, Pires JSR, Nordi N: Contribuição ao manejo participativo do caranguejo-uçá Ucides cordatu (Linnaeus, 1763), em Cananeia - SP. Boletim do Instituto de Pesca 2006, 32:221-228.

11. Nascimento DM, Mourão JS, Rocha PD, Ferreira EM, Bezerra DMMSQ: Impactos socioambientais provocados pela técnica "redinha" na captura do caranguejo-uçá Ucides cordatuno estuário do Rio Mamanguape (PB) [abstract]. IX Encontro de Biologia da UEFS \& IV Encontro Nordestino de Etnoecologia e Etnobiologi. UEFS, Feira de Santana 2008, 1:542.

12. Nordi N: Os catadores de caranguejo-uçá (Ucides cordatus) da região de Várzea Nova (PB): uma abordagem ecológica e social. Tese Doutorado Universidade Federal de São Carlos, Departamento de Ecologia e Recursos Naturais; 1992.

13. Nishida AK, Nordi N, Alves RRN: Abordagem Etnoecológica da coleta de moluscos no Litoral Paraibano. Tropical Oceanography 2004, 32:53-68.

14. Melo GAS: Manual de identificação dos Brachyura (caranguejos e siris) do litoral brasileiro. 1 edition. São Paulo: Plêiade; 1996.

15. Botelho ERRO, Santos MCF: A cata de crustáceos e moluscos no manguezal do Rio Camaragibe - Estado de Alagoas: aspectos socioambiental e técnico-econômico. Boletim Técnico-Científico do CEPENE 2005, 13:77-96.

16. Botelho ERRO, Santos MCF, Souza JRB: Aspectos populacionais do goiamum, Cardisoma guanhum Latreille, 1825, do estuário do rio Una Pernambuco - Brasil. Boletim Técnico-Científico do CEPENE 2001, 9:123-146.

17. Soffiati $A: D a$ mão que captura o caranguejo à globalização que captura o manguezal: II Encontro da ANPPAS.[http://www.anppas.org.br/ encontro_anual/encontro2/GT/GT08/arthur_soffiati.pdf].

18. Amaral $A C Z$, Jablonski $\mathrm{S}$ : Conservação da biodiversidade marinha e costeira no Brasil. Megadiversidade 2005, 1:43-51.

19. Ministério do Meio Ambiente (MMA): Lista Nacional das espécies de invertebrados aquáticos e peixes sobreexplotadas ou ameaçadas de sobreexplotação. Instrução normativa no. 5, de 21 de maio de 200. Diário Oficial da União 2004, 102:136-142.

20. Silva OC, Coelho PA: Estudo ecológico da Barra das Jangadas (Nota Prévia). Trabalhos do Instituto de Biologia Marítima e Oceanográfica da Universidade Federal de Pernambuco 1960, 1:46-235.

21. Coelho PA: Os Crustáceos Decápodos de alguns manguezais pernambucanos. Trabalhos do Instituto de Biologia Maritima e Oceanográfica da Universidade Federal de Pernambuco 1967, 8:71-90.

22. Farias MDCQ: Crustáceos decápodos da llha da Restinga. Boletim do Instituto Oceanográfico 1980, 29:169-172.

23. Coelho Filho PA, Coelho-Santos MA, Farrapeira CM: Zonação vertical da macrofauna bêntica de substratos inconsolidados do estuário do Rio Paripe (Itamaracá - Pernambuco) [abstract]. Mangrove 2000, International Conference, Sustainable use of Estuaries and Mangroves Recife 2000, 1:18.

24. Alves RRN, Souto WMS: Ethnozoology in Brazil: current status and perspectives. Journal of Ethnobiology and Ethnomedicine 2011, 7:1-22.

25. Carvalho HRL, Igarashi MA: A utilização do forjo na captura do caranguejo uçá (Ucides cordatu) na comunidade de Tapebas em Fortaleza - CE. Biotemas 2009, 22:69-74.

26. Fiscarelli AG, Pinheiro MAA: Perfil socioeconômico e conhecimento etnobiológico do catador do caranguejo-uçá,Ucides cordatu(Linnaeus, 1763) nos manguezais de Iguape (24 41S), SP, Brasil. Actualidades Biologicas 2002, 24:129-142.

27. Nordi N: A produção dos catadores do caranguejo-uçá (Ucides cordatu) da região de Várzea Nova, Paraíba. Revista Nordestina de Biologia 1994, 9:71-77.

28. Nordi N: O processo de comercialização do caranguejo-uçá (Ucides cordatu) e seus reflexos nas atividades de coleta. Revista Nordestina de Biologia 1995, 10:39-45

29. Nordi N, Nishida AK, Alves RRN: Effectiveness of two gathering techniques for Ucides cordatu in Northeast Brazil: implications for the sustainability of mangrove ecosystems. Hum Ecol 2009, 37:121-127.

30. Alves RRN, Nishida AK: A ecdise do caranguejo-uçá, Ucides cordatu (Crustacea, Decapoda, Brachyura) na visão dos caranguejeiros. Interciencia 2002, 27:110-117.

31. Souto FJB: Uma abordagem etnoecológica da pesca do caranguejo, Ucides cordatu, Linnaeus, 1763 (Decapoda: Brachyura), no manguezal do Distrito de Acupe (Santo Amaro-BA). Biotemas 2007, 20:69-80.

32. Marques JGW: Pescando Pescadores: etnoecologia abrangente no baixo Säo Francisco Alagoano São Paulo: NUPAUB - USP; 1995.

33. Alves AG, Souza RM: Etnoecologia de um ambiente estaurino no nordeste do Brasil: Conhecimento dos "mariscos" (Mollusca:Bivalvia) por mulheres no Canal de Santa Cruz [abstract]. Anais do MANGROVE Recife 2000, 1:528.

34. Hanazaki N: Conhecimento caiçara para o manejo de recursos naturais. In Atualidade em etnobiologia e etnoecologia. Volume 1.. 1 edition. Edited by: Albuquerque UP, Alves AGC, Lins \& Silva ACB, Silva VA. Recife: SBEE/NUPEA; 2002:17-25.

35. Costa-Neto EM: Implications and applications of folk zootherapy in the State of Bahia, Northeastern Brazil. Sustain Dev 2004, 12:161-174.

36. Dias Neto J: Proposta de Plano Nacional de Gestão para o uso sustentável do Caranguejo-Uçá do Guaiamum e do Siri-Azul Brasília: IBAMA; 2011.

37. Origem Consultoria: Cadastro de Fontes Poluidoras dos Recursos Hídricos do Município de Mucuri Mucuri/BA; 2000.

38. Barros CMB: Conhecimento Tradicional, Conservação e Sobrevivência: A importância da participação dos caranguejeiros na definição de políticas de proteção e manejo do manguezal de Mucuri - Bahia. Dissertação Mestrado Universidade Federal de Alagoas, Departamento de Biologia; 2001.

39. Bailey KD: Methods of Social Research. 4 edition. New York: The Free Press; 1982.

40. Spradley JP: The Ethnographic Interview Fort Worth: Harcourt Brace Jovanovich College Publishers; 1979.

41. Sttebins RA: Fitting in: the researcher as leaner and participant. Qual Quant 1987, 21:103-108.

42. Marques JGW: O Olhar (Des) Multiplicado. O Papel do Interdisciplinar e do Qualitativo na Pesquisa Etnobiológica e Etnoecológica. In Métodos de Coleta e Análise de Dados em Etnobiologia, Etnoecologia e Disciplinas Correlatas Anais do I Encontro de Etnobiologia e Etnoecologia do Sudeste. Edited by: Amorozo McM, Ming LC, Silva SMP. Rio Claro: Cacb/unesp Cnpq; 2002:31-45.

43. Viertler RB: Métodos Antropológicos como ferramenta para estudos em Etnobiologia e Etnoecologia. In Métodos de Coleta e Análise de Dados em Etnobiologia, Etnoecologia e Disciplinas Correlatas Anais do I Encontro de Etnobiologia e Etnoecologia do Sudeste. Edited by: Amorozo MCM, Ming LC, Silva SMP. Rio Claro: Cacb/unesp-Cnpq; 2002:11-29.

44. Marques JGW: Aspectos Ecológicos dos Pescadores do Complexo Estuarino-Lagunar Mandaú-Manguaba, Alagoas. Tese Doutorado Universidade Estadual de Campinas, Departamento de Biologia Animal; 1991.

45. Soares MLG: Estudo da biomassa aérea de manguezais do sudeste do Brasil - Análise de modelos. Tese Doutorado. Universidade de São Paulo, Instituto Oceanográfico; 1997.

46. Oliveira LPH: Estudos ecológicos dos crustáceos comestíveis uçá e guaiamú, Cardisoma guanhum Latreille e Ucides cordatu (L). Gecarcinidae, Brachyura. Memórias do Instituto Oswaldo Cruz 1946, 44:123-143.

47. Branco JO: Aspectos ecológicos de Brachyura (Crustacea: Decapoda) no manguezal do Itacorubi, SC, Brasil. Revista Brasileira de Zoologia 1990, 7:165-179.

48. Hill K: Cardisoma guanhumi Smithsonian Marine Station at Fort Pierce; 2001 [http://www.sms.si.edu/RLSpec/Cardis_guanhu.htm].

49. Hostetler ME, Mazzotti FJ, Taylor AT: Blue Land Crab (Cardisoma guanhumi). Wec 30 of University of Florida, IFAS Extension 2003 [http://edis. ifas.ufl.edu/pdffiles/UW/UW01300.pdf].

50. Souto FJB: A ciência que veio da lama: uma abordagem etnobiológica abrangente das relações ser humano/manguezal na comunidade pesqueira de Acupe, Santo Amaro-BA. Tese Doutorado Universidade Federal de São Carlos, Instituto de Ecologia; 2004.

51. Leite LMAB: Estudo Etnocarcinológico do Cardisoma guanhumi Latreille, 1825(Crustácea, Brachyura, Gecarcinidae) no Estuário do rio Gioana, Pernambuco, Brasil. Tese Doutorado Universidade Federal da Paraíba. Programa de Pós-Graduação em Ciências Biológicas (Zoologia), Departamento de Sistemática e Ecologia; 2005.

52. Alves RRN, Nishida AK, Hernandez MIM: Environmental perception of gatherers of the crab 'caranguejo-ucá' (Ucides cordatu, Decapoda, Brachyura) affecting their collection attitudes. Journal of Ethnobiology and Ethnomedicine 2005, 1:10

53. Souto FJB, Marques JGW: "O siri labuta muito!" Uma abordagem etnoecológica abrangente da pesca de um conjunto de crustáceos no manguezal de Acupe, Santo Amaro, Bahia, Brasil. Sitientibus - Série Ciências Biológicas (Etnobiologia) 2006, 6:106-119.

54. Maciel DC, Alves AGC: Conhecimentos e práticas locais relacionados ao aratu Goniopsis cruentat (Latreille, 1803) em Barra de Sirinhaém, litoral sul de Pernambuco. Biota Neotropica 2009, 9:29-36. 
55. Pinheiro MAA, Fiscarelli AG: Manual de apoio à fiscalização do caranguejo uçá (Ucides cordatus). Itajaí: IBAMA/CEPSUL; 2001

56. Schmidt AJ, Oliveira MA: Plano de ação para o caranguejo-uçá em Canavieiras Brazil: Canavieiras Press; 2006.

57. Gifford CA: Some observations on the general biology of the land crab Cardisoma guanhum (Latreille) in Salt Florida. Biol Bull 1962, 123:207-223.

58. Wenner AM: Sex-ratio as a function of size in marine Crustacea. The Americam Naturalist 1972, 106:321-350.

59. Margalef R: Ecologia Barcelona: Omega; 1977.

60. Takahashi MA: Conhecimentos locais e a cadeia produtiva do goiamum (Cardisoma guanhumi, Lattreille, 1825) no litoral paraibano. Dissertação Mestrado Universidade Federal da Paraíba, Programa de Pós-Graduação em Desenvolvimento e Meio Ambiente; 2008.

61. Maneschy MC: Pescadores nos manguezais: estratégias técnicas e relações sociais de produção na captura de caranguejo. In Povos das Águas realidade e perspectiva na Amazônia. Edited by: Furtado L, Mello AF, Leitão W. Belém: MPEG/UFPa; 1993:243-276.

62. Nunes AGA: Os argonautas do mangue: uma etnografia visual dos caranguejeiros do Município de Vitória - ES Instituto de Artes: Dissertação Mestrado. Universidade Estadual de Campinas; 1998.

63. Botelho ERRO, Dias AF, Ivo CTC: Estudo sobre a biologia do caranguejouçá Ucides cordatus cordatu, (Linnaeus, 1763), capturado nos estuários dos rios Formoso (Rio Formoso) e llhetas (Tamandaré), no Estado de Pernambuco. Boletim Técnico-Científico do CEPENE 1999, 7:117-145.

64. Fiscarelli AG, Pinheiro MAA: Perfil socioeconômico e conhecimento etnobiológico do catador de caranguejo-uçá, Ucides cordatu (Linnaeus, 1763), nos manguezais de Iguape ( $\left.24^{\circ} 41^{\prime} \mathrm{S}\right)$, SP, Brasil. Actual Biology 2002, 24:129-142.

65. Bright $\mathrm{DB}$, Hogue $\mathrm{CL}$ : A sinopsis of the burrowing land crabs of the world and list of their arthropod symbionts and burrow associates. Contributions in Science 1972, 220:1-58.

66. Silva R, Oshiro LMY: Aspectos reprodutivos do caranguejo Guaiamum, Cardisoma guanhum Latreille, 1828 (Crustacea, Decapoda, Brachyura) da Baía de Sepetiba, RJ. Revista Brasileira de Zoologia 2002, 19:71-78.

67. Gaião LO: Saberes tradicionais e percepção ambiental dos catadores de caranguejos do município de canavieiras, Bahia, acerca do guaiamum, cardisoma guanhumi (Latreille, 1825). Dissertação Mestrado Universidade Estadual de Santa Cruz, Programa de Pós-Graduação em Desenvolvimento Regional e Meio Ambiente; 2007.

68. Nunes AA, Samain E: Os argonautas do mangue precedido de Balinese character (re) visitado Editora Unicamp/São Paulo: Imprensa Oficial do Estado de São Paulo; 2004.

69. Nascimento AS: Biology of the land crab, Ucides cordatus Aracaju: ADEMA State Administration of Environment; 1993.

70. Nascimento AS: Estudo bio-ecológico do caranquejo-uçá e das características dos manguezais do Estado de Sergipe Aracajú: Relatório Técnico da ADEMA; 1984.

71. Greenaway P: Calcium and magnesium balance during molting in land crabs. J Crustac Biol 1993, 13:191-197.

72. Ríos-Jara E: Effects of lunar cycle and substratum preference on zooplankton emergence in a tropical, shallow-water embayment, in southwestern Puerto Rico. Caribeean Journal of Science 2005, 41:108-123.

73. Nishida AK, Nordi N, Alves RRN: The lunar-tide cycle viewed by crustacean and mollusc gatherers in the State of Paraiba, Northeast Brazil and their influence in collection attitudes. Journal of Ethnobiology and Ethnomedicine 2006, 2:1-12.

74. Mourão JS: Classificação e ecologia de peixes estuarinos por pescadores do Estuário do Rio Mamanguape - PB. Tese Doutorado Universidade Federal de São Carlos. Programa de Pós-Graduação em Ecologia e Recursos Naturais, Departamento de Ecologia; 2000.

75. Costa-Neto EM: O Caranguejo de água doce, Trichodactylus uviatili (Latreille, 1828) (Crustacea, Decapoda, Trichodactylidae), na concepção dos moradores do Povoado de Pedra Branca, Bahia, Brasil. Biotemas 2007, 20:59-68.

76. Boeger WA, Pie MR, Ostrensky A, Patella L: Lethargic crab disease: multidisciplinary evidence supports a mycotic etiology. Memórias do Instituto Oswaldo Cruz 2005, 100:161-167.

77. Orélis-Ribeiro R, Boeger WA, Vicente VA, Chammas M, Ostrensky A: Fulfilling Koch's postulates confirms the mycotic origin of Lethargic Crab Disease. Antonie Van Leeuwenhoek 2011, 99:601-608.
78. Schaeffer-Novelli Y: Perfil dos ecossistemas litorâneos brasileiros, com especial ênfase sobre o ecossistema manguezal. Instituto Oceanográfico 1989, 7:1-16

79. Soffiati A: As pressões do comércio sobre a captura do gaiamum [abstract]. III Encontro Nordestino de Educação Ambiental em Áreas de Manguezal 2001, 23:s42.

80. Franco MVG: Partilhando saberes: educação ambiental na Vila de Garapua, município de Cairú-BA Monografia de Graduação, Universidade Federal da Bahia.

81. Brunet JMS: Aratus, caranguejos, siris e guaiamuns, animais do manguezal: uma etnografia dos saberes, técnicas e práticas dos jovens da comunidade pesqueira de Baiacu (llha de Itaparica-BA). Dissertação Mestrado Universidade Federal da Bahia/Universidade Estadual de Feira de Santana, Salvador. Instituto de Ensino História e Filosofia das Ciências; 2006.

82. Botelho ERRO, Santos MCF, Pontes ACP: Algumas considerações sobre o uso da redinha na captura do caranguejo-uçá Ucides cordatu (Linnaeus, 1763) no litoral sul de Pernambuco - Brasil. Boletim Técnico-Científico do CEPENE 2000, 8:7-55.

83. Bem BNC: Viver da água e do mangue: uma abordagem ecológica e social das comunidades pesqueiras nos estuários do Catuama e Itapessoca - PE. Dissertação Mestrado Universidade Federal da Paraíba, Programa de Pós-Graduação em Desenvolvimento e Meio Ambiente.

84. Maitland DP: Convergent design of Caribbean and Phillippine bamboo land-crab traps. J Crustac Biol 2002, 22:497-501.

85. Pacheco RS: Aspectos da ecologia de pescadores residentes na península de Maraú - BA: pesca, uso de recursos marinhos e dieta. Dissertação Mestrado Programa de Pós-Graduação em Ecologia da Universidade de Brasília; 2006.

86. Duarte CBG: Manguezal do delta dos rios Peruipe, Pituaçu e Caravelas: alternativas para o ordenamento da captura do caranguejo-uçá (Ucides cordatus L.) propiciando a sustentabilidade da espécie e das comunidades tradicionais - Nova Viçosa e Caravelas - Bahia Monografia de Graduação, Universidade do Estado da Bahia; 2004.

87. Lima TMA: Teia de sincretismo: uma introdução à poética dos mangues. Tese Doutorado Universidade Federal do Pernambuco, Centro de Artes e Comunicação; 2007.

88. Instituto Brasileiro do Meio Ambiente e dos Recursos Naturais Renováveis (IBAMA): Instrução Normativa 90 de 02 de fevereiro de 2006. Do Ministério do Meio Ambiente 2006.

doi:10.1186/1746-4269-8-12

Cite this article as: Firmo et al:: Capture and commercialization of blue land crabs ("guaiamum") Cardisoma guanhumi (Lattreille, 1825) along the coast of Bahia State, Brazil: an ethnoecological approach. Journal of Ethnobiology and Ethnomedicine 2012 8:12.

\section{Submit your next manuscript to BioMed Central and take full advantage of:}

- Convenient online submission

- Thorough peer review

- No space constraints or color figure charges

- Immediate publication on acceptance

- Inclusion in PubMed, CAS, Scopus and Google Scholar

- Research which is freely available for redistribution

Submit your manuscript at www.biomedcentral.com/submit
C Biomed Central 